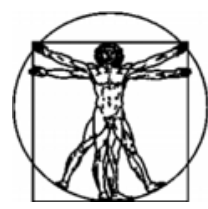

\title{
МОДЕЛИРОВАНИЕ МОРФОЛОГИИ ЭРИТРОЦИТА И РАСЧЕТ ВНУТРИКЛЕТОЧНОГО ДАВЛЕНИЯ ПО ДАННЫМ АТОМНО-СИЛОВОЙ МИКРОСКОПИИ
}

\author{
Ю.С. Нагорнов ${ }^{1}$, Р.А. Пахомова ${ }^{2}$, И.В. Жиляев ${ }^{3}$, Е.А. Воронова ${ }^{2}$ \\ 1 Тольяттинский государственный университет, Россия, 445667, Тольятти, ул. Белорусская, 14б, e-mail: \\ Nagornov.Yuri@gmail.com \\ 2 Красноярский государственный медицинский университет имени профессора В.Ф. Войно-Ясенецкого, \\ Россия, 660022, Красноярск, ул. Партизана Железняка, 1 \\ 3 Южный федеральный университет, Россия, 344006, Ростов-на-Дону, ул. Большая Садовая, 105/42, \\ e-mail: Zhilyaev@mail.com
}

\begin{abstract}
Аннотация. Настоящая работа посвящена анализу трехмерных данных атомносиловой микроскопии по исследованию морфологии эритроцитов. Атомно-силовая микроскопия позволяет анализировать биомеханические свойства мембраны эластичность, мобильность поверхностных слоев, адгезию, молекулярное связывание и электростатичность. Построена биомеханическая модель эритроцита, которая позволила провести расчет внутриклеточного давления эритроцитов на основе данных атомно-силовой микроскопии. В модели упругие свойства эритроцита определяются ригидностью его мембраны и взаимодействием с гемоглобином, при этом внутреннее содержимое эритроцита принималось за однородное тело. Расчет проводился в два этапа: сначала для подвижного содержимого эритроцита с использованием уравнений Навье-Стокса, где содержимое эритроцита представлялось в виде жидкости с параметризацией начального давления и формированием геометрии под действием внутренних и внешних сил, а затем расчет проводился повторно методом конечных элементов, при этом внутреннее содержимое эритроцита предполагалось твердым, что исключало движение внутри эритроцита, но позволяло определить внутреннее давление, которое устанавливается в равновесии. В результате была получена зависимость внутриклеточного давления от морфологии эритроцита. Предложен способ оценки внутриклеточного давления эритроцитов на основе численного моделирования и данных атомно-силовой микроскопии скана эритроцитов, который предполагает сравнение экспериментальных данных с результатами численного расчета. Способ применен к данным атомно-силовой микроскопии эритроцитов экспериментальных животных - карликовых домашних свиней при разной степени механической желтухи и в норме. Показано, что с ростом степени заболевания и концентрации билирубина в крови происходит нарушение мембраны эритроцитов, в среднем увеличение их объема и существенное изменение внутриклеточного давления по отношению к показателю в норме.
\end{abstract}

Ключевые слова: эритроцит, биомеханика мембраны, внутриклеточное давление, атомно-силовая микроскопия, механическая желтуха.

(C) Нагорнов Ю.С., Пахомова Р.А., Жиляев И.В., Воронова Е.А., 2015

Нагорнов Юрий Сергеевич, к.ф.-м.н., доцент, старший научный сотрудник, Тольятти

Пахомова Регина Александровна, к.м.н., доцент кафедры общей хирургии, Красноярск

Жиляев Игорь Витальевич, аспирант кафедры математического моделирования, Ростов-на-Дону

Воронова Елена Александровна, аспирант кафедры общей хирургии, Красноярск 


\section{ВВЕДЕНИЕ}

Метод атомно-силовой микроскопии находит все более широкое применение в биологии и медицине. Атомно-силовая микроскопия имеет ряд преимуществ перед оптическим или электронным микроскопами. Помимо трехмерной визуализации, атомно-силовая микроскопия имеет возможность анализа механических свойств, что позволяет более глубоко изучать клеточные процессы, выяснять такие важнейшие свойства, как эластичность, мобильность поверхностных слоев, адгезия, молекулярное связывание и электростатичность.

В настоящее время формируется новое направление в цитологии, которое определяют термином «клеточная наномеханика», или «клеточная эластография». Эти понятия подразумевают методы визуализации сдвиговых упругих характеристик биологических мягких тканей, которые дополняют традиционные способы визуализации и считаются перспективными для медицинской диагностики различных патологий, особенно при изучении онкологических заболеваний $[1,6,7,10,13-15,20]$.

Работы по изучению биологических объектов с помощью методов атомносиловой микроскопии активно ведутся в отношении красных клеток крови эритроцитов. Изменение формы эритроцитов может возникать вследствие внешних физико-химических воздействий, т.е. клетки могут подвергаться различным обратимым и необратимым трансформациям. Состояние мембраны эритроцитов и работы ионных насосов мембраны однозначно меняет внутриклеточное осмотическое давление, что, в свою очередь, изменяет морфологию эритроцита и его объем.

Взаимосвязь между состоянием мембраны эритроцита и его внутриклеточным давлением и морфологией можно описать следующим образом. Исходя из термодинамического принципа минимизации свободной энергии липидного бислоя мембраны в работах [13, 20] трехмерная форма эритроцита рассчитывается аналитически. На основании этого и модели регуляции ионного обмена и, соответственно, объема эритроцитов в работах $[7,14,15]$ приводятся численный расчет взаимосвязи внутриклеточного давления и объема эритроцита, в том числе с учетом биомеханической модели оболочки [1, 15]. Данные модели согласуются с экспериментальными данными, подтверждающими изменение объема эритроцита при изменении ионного обмена под действием различных внешних химических факторов, изменяющих рН раствора.

Однако для сравнения расчетных данных с экспериментальными данными, полученными методами атомно-силовой микроскопии, указанные модели необходимо дополнить по нескольким причинам $[1,4-6,8,9,11,12,16-19]$. Во-первых, измерение методами атомно-силовой микроскопии наиболее часто проводится в воздушной среде, в которой эритроцит теряет до 70 \% массы из-за потери воды. В результате форма эритроцита не меняется, а его объем на 95-99 \% заполнен гемоглобином $[1,10]$, в то время как в работах $[7,14,15]$ предполагалось, что содержание гемоглобина находится в диапазоне 50-80 \%. Во-вторых, соотношение объем-давление в термодинамической системе, в которой происходит существенное влияние гемоглобина на мембрану эритроцита, будет меняться, что кратко упоминается в работах [1, 7]. Так, в работе [7] был изучен процесс расширения эритроцита под действием внутреннего давления, которое менялось в широком диапазоне - от единиц паскалей до 5 кПа. Расширение до 40-60 \% по отношению к начальному объему происходило под действием небольшого давления до 2 Па за счет изменения формы, затем модель эритроцита приобретала форму шара и расширение происходило за счет растяжения мембраны, что требует на три порядка больше давления. При этом моделирование уменьшения объема из-за обезвоживания или под действием сил сжатия выполнено не было. И, наконец, при 
экспериментальном исследовании методами атомно-силовой микроскопии происходит осаждение эритроцитов на поверхность, их адгезия и изменение формы под действием сил адгезии и тяжести $[4,5,11,12,17,18]$. Таким образом, целью настоящей работы является численный расчет морфологии эритроцита в зависимости от внутриклеточного давления для анализа данных атомно-силовой микроскопии, т.е. для случая, когда эритроцит находится в воздушной среде на предметном стекле.

\section{МОДЕЛЬ ЭРИТРОЦИТА И ЧИСЛЕННЫЙ РАСЧЕТ МОРФОЛОГИИ}

Существует ряд моделей, которые описывают процессы регуляции ионного обмена и объема эритроцитов $[1,6,7,10,13-15,20]$. Основное внимание в этих работах уделено биохимическим и электрохимическим процессам, влияющим на регулирование объема. Показано, что система ионных насосов и каналов в мембране клетки $\left(\mathrm{Na}^{+}\right.$, $\mathrm{K}^{+}$-насос, $\mathrm{Ca}_{2}^{+}$-активируемые $\mathrm{K}^{+}$-каналы) обеспечивает заданный объем клетки и его стабилизацию. Перенос ионов осуществляется при помощи ферментов класса гидролаз аденозинтрифосфатазы, катализирующих отщепление от аденозинтрифосфорной кислоты одного или двух остатков фосфорной кислоты. В процессе биохимической реакции происходит освобождение энергии, используемой при транспорте веществ через мембрану. Высокое соотношение концентрации калия во вне- и внутриклеточной жидкости (38:1) поддерживается благодаря действию $\mathrm{Na}^{+}, \mathrm{K}^{+}$-аденозинтрифосфатазы, активно переносящей ионы калия в клетку, а ионы натрия из нее в соотношении 2:3 [6]. Вследствие активного выведения натрия из клеток $\mathrm{Na}^{+}, \mathrm{K}^{+}$-аденозинтрифосфатазы 85-90 \% всего натрия, содержащегося в организме, находится во внеклеточной жидкости. Аденозинтрифосфатаза белков плазматических мембран осуществляет аденозинтрифосфатазозависимый трансмембранный перенос $\mathrm{Na}^{+}$и $\mathrm{K}^{+}$-ионов в клетках, что обеспечивает поддержание электрохимического и осмотического градиентов одновалентных ионов, необходимых для нормального функционирования клеток.

В результате работы ионных каналов в клетке возникает асимметрия в распределении концентраций ионов внутри и вне клетки, что обеспечивает поддержание еe постоянного объема. Создаваемое обменными процессами осмотическое давление в клетке эритроцита вызывает деформацию оболочки. При этом морфология эритроцита задается липидным бислоем, что определяется внутренними силами, возникающими вследствие построения белков слоя (фосфолипидов) неполярными концами внутрь слоя. Возникающая из-за ионного взаимодействия механическая энергия липидного бислоя стремится принять минимальное значение и формирует морфологию эритроцита $[1,2,9]$.

Для расчета влияния ионных насосов на регуляцию объема эритроцита составляют систему уравнений $[1,6,7,10,14,15]$, которая включает потоки ионов и поток воды. При этом известно [1], что основной вклад в регуляцию объема эритроцитов человека вносят катионы калия и натрия, а также анионы хлора и $\mathrm{HCO}_{3}$. Кинетика внутриклеточных концентраций калия и натрия описывается уравнениями, которые учитывают активный транспорт этих катионов $\mathrm{Na}^{+}, \mathrm{K}^{+}$-аденозинтрифосфатазы и пассивный поток через мембрану по градиенту концентрации. Учитывая условие электронейтральности внутриклеточного содержимого эритроцита, получают известное уравнение зависимости изменения объема от осмотического давления в эритроците:

$$
\frac{d}{d t}\left(\frac{V}{V_{0}}\right)=J_{\mathrm{H}_{2} \mathrm{O}}=\frac{S P_{f}}{V_{0}} \vartheta_{\mathrm{H}_{2} \mathrm{O}} \Delta C=\frac{S P_{f}}{V_{0}} \vartheta_{\mathrm{H}_{2} \mathrm{O}} \frac{\Delta P}{R T},
$$


где $V$ и $V_{0}$ - текущее и физиологически нормальное значение объема эритроцита, а поток воды $J_{\mathrm{H}_{2} \mathrm{O}}$ пропорционален разности концентраций $\Delta C$ осмотически активных ионов внутри и снаружи мембраны эритроцита, которая выражается через осмотическое давление $\Delta P$ и тепловой потенциал $R T ; S$ - площадь мембраны, $\vartheta_{\mathrm{H}_{2} \mathrm{O}}-$ молярный объем воды и $P_{f}$ - осмотическая проницаемость мембраны для воды.

В работах [3, 7] был выполнен численный расчет уравнения (1) с учетом упругого воздействия оболочки на обменные процессы и изменения объема эритроцита. Благодаря способности сопротивляться деформированию оболочка эритроцита оказывает воздействие на процесс осмоса в виде реактивного давления $\Delta P_{r}$, которое приложено к объему, заключенному в эритроците. При этом в расчетах по формуле (1) вместо давления $\Delta P$ ставилась разность $\Delta P-\Delta P_{r}$. Модель показала хорошее соответствие с экспериментальными данными об увеличении объема эритроцита в процессе образования ионных каналов в мембране после обработки эритроцитов амфотерицином $B$ и вызванного этим увеличения проницаемости для ионов, а также об увеличении объема по причине уменьшения осмотичности среды [7].

В случае проведения измерений при помощи атомно-силового микроскопа наиболее часто параметры эритроцита определяются с использованием мазка крови на стекле, где эритроциты расположены тонким слоем и находятся в воздушной среде. Как было показано в работах $[1,4,5,8,9,11,16-18]$, на воздухе происходит выход воды из эритроцита и, соответственно, уменьшение его объема в 4-6 раз. Поскольку при измерениях с помощью атомно-силовой микроскопии в процессе высушивания образца с эритроцитами водная среда исчезает, возникает большой градиент $\Delta P$, в соответствии с формулой (1) происходит выход воды из эритроцита и потеря его массы и объема. При этом форма эритроцита остается неизменной и определяется состоянием его мембраны $[1,4,5,8,9,11,16-18]$, т.е. реактивным давлением $\Delta P_{r}$.

С одной стороны, реактивное давление мембраны эритроцита $\Delta P_{r}$ будет зависеть от состояния мембраны, с другой стороны, морфология эритроцита будет зависеть от биомеханики его мембраны $[8,9,13,16,18,20]$. Таким образом, для определения внутриклеточного давления по данным атомно-силовой микроскопии необходимо провести численный расчет, в котором задается начальное реактивное давление $\Delta P_{r}$, и получить зависимости морфологии эритроцита от его величины.

За основу модели для численного расчета были взяты известные справочные данные и биомеханическая модель однородного тела, покрытого мембраной, состоящей из липидного бислоя, упругие свойства которого описаны в работах $[13,20]$ и задаются несимметричным тензором, что формирует морфологию эритроцита. Для решения системы уравнений использовался программный продукт PARDISO (Parallel Direct Solver), библиотечная подпрограмма которого применялась для решения системы линейных уравнений с невырожденной разреженной матрицей методами суперузлового исключения Гаусса, а также разложениями Холецкого. Для проведения численного расчета методом конечных элементов применялся программный комплекс Comsol multiphysics (лицензия 1029477) и модуль оптимизации пакета прикладных программ MATLAB (лицензия 512916) [8, 9, 16, 18].

Для численного моделирования рассматривалась связная задача взаимодействия твердого тела (мембрана клетки) и жидкости (внутреннее содержимое эритроцита). В работе решалась параметрическая задача, в качестве параметра использовалось значение реактивного давления $\Delta P_{r}$, создаваемого мембраной эритроцита, геометрия эритроцита представлена на рис. $1, a$. В расчетах принимались следующие обозначения осей координат: $r$ - горизонтальная, $z$ - вертикальная, $\varphi-$ угловая. В численном 
эксперименте рассматривается осесимметричная задача, ось тела вращения проходит через центр эритроцита $(r=0)$. В расчетах модель линейного эластичного материала основывалась на следующих уравнениях:

$$
\begin{gathered}
-\nabla \sigma=F_{V}, \sigma=S, \\
s-S_{0}=C:\left(\varepsilon-\varepsilon_{0}-\varepsilon_{\text {inel }}\right), \\
\varepsilon=\frac{1}{2}\left[\left(\nabla u_{\text {solid }}\right)^{T}+\nabla u_{\text {solid }}\right],
\end{gathered}
$$

где $\sigma$ - тензор напряжений, $\sigma=S ; F_{V}$ - сила, действующая на тело; $\varepsilon$ - тензор деформаций; $\varepsilon_{\text {inel }}$ - тензор тепловой деформации; $S_{0}, \varepsilon_{0}-$ начальные значения соответствующих тензоров; $C$ - тензор упругости четвертого порядка; “:” - операция тензорного произведения; $u_{\text {solid }}$ - вектор компоненты смещения, для расчетов мембраны применяется модель эластичного материала.
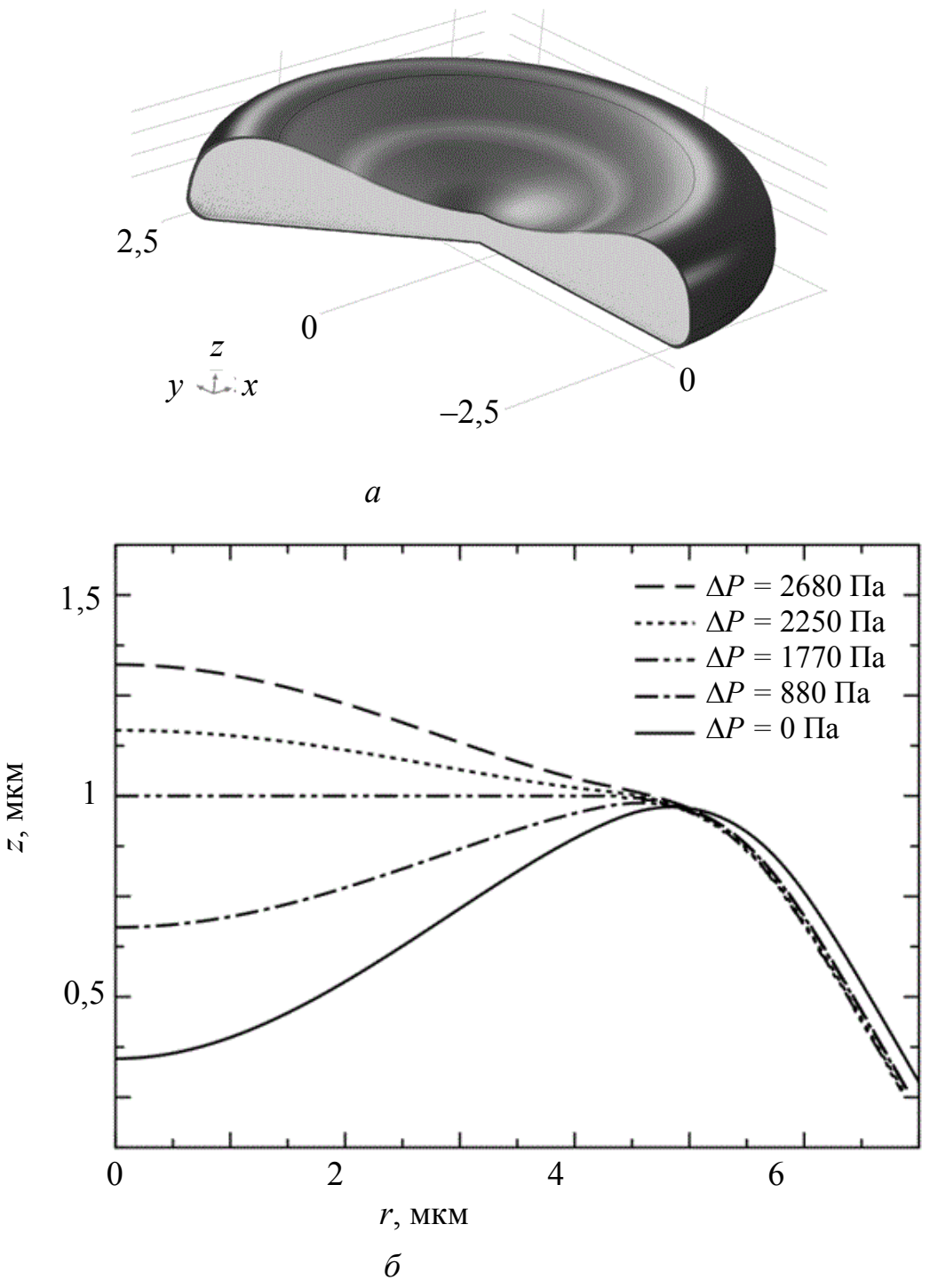

Рис. 1. Результаты расчета морфологии модели эритроцита под действием давления: $a$ - трехмерная модель эритроцита, на которой показан боковой срез; $\sigma$ - зависимость формы среза эритроцита от разности давлений на мембрану эритроцита, отрицательные значения - давление внутри превышает давление снаружи 
При этом начальные смещения равны 0, на внешней границе твердого тела задаются начальные и граничные условия следующего вида:

$$
\sigma \cdot n=F_{A}, \quad F_{A}=\left(\begin{array}{c}
0 \\
\Delta P_{r}
\end{array}\right),
$$

где $n$ - нормаль к поверхности; $F_{A}$ - вектор внешнего воздействия; $\Delta P_{r}$ - реактивное давление, задаваемое в расчетах как параметр. Данное условие обеспечивает направление вектора давления вдоль вертикальной оси. На оси вращения установлено условие симметрии. Нижняя граница эритроцита зафиксирована от смещений вдоль оси $z$ :

$$
w_{\text {solid }}=0 .
$$

Физические свойства твердого тела задаются в соответствии с известными экспериментальными данными $[1,3,9,19]$ : модуль упругости оболочки равен 1200 2000 Па в зависимости от координаты $r$ [5, 8, 9, 16-18], плотность оболочки 1200 кг $/ \mathrm{m}^{3}[3,13,10,20]$, коэффициент Пуассона оболочки - 0,33 [5, 7, 9]. Тензор деформации обусловлен упругими свойствами мембраны: жесткостью на сдвиг, равной $0,006 \mathrm{MH} / \mathrm{M}$, и на растяжение, равной $450 \mathrm{мH} / \mathrm{м}[1,7]$. При этом математическая модель гидродинамики описывает поведение внутреннего содержимого модели эритроцита, существенное отличие от модели мембраны состоит в том, что жидкое содержимое может двигаться и изменять свое местоположение в зависимости от приложенного давления со стороны мембраны. В результате во внутренней области эритроцита проводится моделирование жидкой среды с использованием уравнений Навье-Стокса и неразрывности:

$$
\begin{gathered}
\rho\left(u_{\text {fluid }} \cdot \nabla\right) u_{\text {fluid }}=\nabla \cdot\left[-p I+\mu\left(\nabla u_{\text {fluid }}+\left(\nabla u_{\text {fluid }}\right)^{T}\right)-\frac{2}{3} \mu\left(\nabla \cdot u_{\text {fluid }}\right) I\right]+F, \\
\nabla \cdot\left(\rho u_{\text {fluid }}\right)=0,
\end{gathered}
$$

где $\rho$ - плотность жидкости; $u_{\text {fluid }}$ - вектор скорости; $p$ - давление жидкости; $I$ - единичный тензор; $\mu$-динамическая вязкость; $F$ - вектор внешних воздействий.

При расчетах считалось, что в начальный момент времени скорость и давление в жидкости равны 0. Условие на границе твердой и жидкой сред позволило отслеживать влияние деформации на объем сжатой жидкости и давление внутри эритроцита и соответствует следующим уравнениям:

$$
\begin{gathered}
u_{\text {fluid }}=u_{w}, \\
u_{w}=\frac{\partial u_{\text {solid }}}{\partial t}, \\
\sigma \cdot n=\Gamma \cdot n, \Gamma=\left[-p I+\mu\left(\nabla u_{\text {fluid }}+\left(\nabla u_{\text {fluid }}\right)^{T}\right)-\frac{2}{3} \mu\left(\nabla \cdot u_{\text {fluid }}\right) I\right],
\end{gathered}
$$

где $u_{w}$ - скорость деформации твердого тела; Г - сила, действующая на границу жидкости и твердого тела.

При этом физические свойства жидкости определяются следующими значениями: плотность жидкости - 1000 кг/м³ 18-20]. В процессе расчетов использовалось конечно-элементное разбиение, в котором сетка содержала порядка 13700 треугольных элементов, при этом размер конечноэлементной ячейки уменьшался при приближении к границе между жидкостью и твердым телом. 
Таким образом, расчет внутриклеточного давления проводился без использования подгоночных параметров в два этапа. Сначала внутреннее содержимое эритроцита представлялось в виде жидкости или подвижного (сыпучего) материала, задавалось давление, осуществлялся расчет и формировалась геометрия под действием внутренних и внешних сил, при этом расчет проводился с использованием уравнений Навье-Стокса. Интересно, что при этом разница давлений на мембрану составляла не более 2 Па, что соответствует данным работ $[1,7]$. Затем расчет проводился повторно методом конечных элементов, при этом внутреннее содержимое эритроцита предполагалось твердым, что исключало движение внутри эритроцита, но позволяло определить внутриклеточное давление, которое устанавливается в равновесии. Естественно, установившееся давление внутри клетки отличалось от начального и принимало значения порядка единиц или десятых килопаскаля, что соответствует данным атомно-силовой микроскопии при измерении модуля Юнга.

На рис. 1, б представлена зависимость формы среза эритроцита от разности давлений на мембрану эритроцита, которая устанавливается после завершения расчета. Видно, что с ростом внешнего давления происходит небольшое расширение модели эритроцита и существенный прогиб в центре мембраны, что соответствует экспериментальным расчетам геометрии среза эритроцита по данным атомно-силовой микроскопии. Необходимо отметить, что при пропорциональном увеличении или уменьшении размеров модели эритроцита установившиеся значения давления внутри клетки не изменялись. Данный факт соответствует теории ионных каналов, поскольку в формуле (1) используется только отношение $V / V_{0}$.

\section{ЭКСПЕРИМЕНТАЛЬНЫЕ РЕЗУЛЬТАТЫ}

Для расчета внутриклеточного давления в работе проведены экспериментальные исследования методом атомно-силовой микроскопии в полуконтактном режиме на микроскопе Solver-P4 компании NT-MDT, при этом в качестве образцов использовались мазки крови, взятые у экспериментальных животных (мини-пигов миниатюрных свинок) с различной степенью заболевания механической желтухой (классы $A, B$ и $C$ ) и у здоровых особей (в норме). Результаты исследований приведены на рис. 2 и 3, при этом показаны только вертикальные срезы эритроцитов (рис. 2, a), которые позволили определить степень изменения глубины впадины мембраны эритроцита в центре и его объем. Полученные усредненные данные измерений по всем эритроцитам на скане приведены в таблице. Механическая желтуха характеризуется тем, что при повышении класса заболевания в крови растет концентрация билирубина, который разрушает мембрану эритроцитов, проникает внутрь, распространяется по организму и приводит к накоплению в печени и других органах [2]. На сканах эритроцитов, полученных с помощью атомно-силовой микроскопии, видно (см. рис. 3), что с ростом степени заболевания происходит рост как количества, так и размеров нарушений в мембране. Кроме этого, оказалось, что в норме эритроцит имеет форму двояковогнутого сфероцита, при нарастании гипербилирубинемии или концентрации билирубина в крови эритроцит меняет форму: из сфероцита превращается в овал, из двояковогнутого становится двояковыпуклым. Все эти данные свидетельствуют о разрушении мембраны эритроцитов и нарушении ее функции, что, вероятно, приводит к изменению ее биомеханических свойств.

По трехмерным данным скана мазка крови был выделен каждый эритроцит в отдельный блок данных, по которым проведен расчет геометрических характеристик разрезов эритроцитов, а также рассчитан объем. Усредненные значения объема эритроцитов и глубины впадины в центре приведены в таблице, в которой также 
представлено расчетное значение внутриклеточного давления для среднего значения отношения $V / V_{0}$.

Видно, что с увеличением степени механической желтухи происходит рост среднего по скану объема эритроцита, соответствующее изменение деформации мембраны в центре эритроцита и увеличение его внутриклеточного давления.

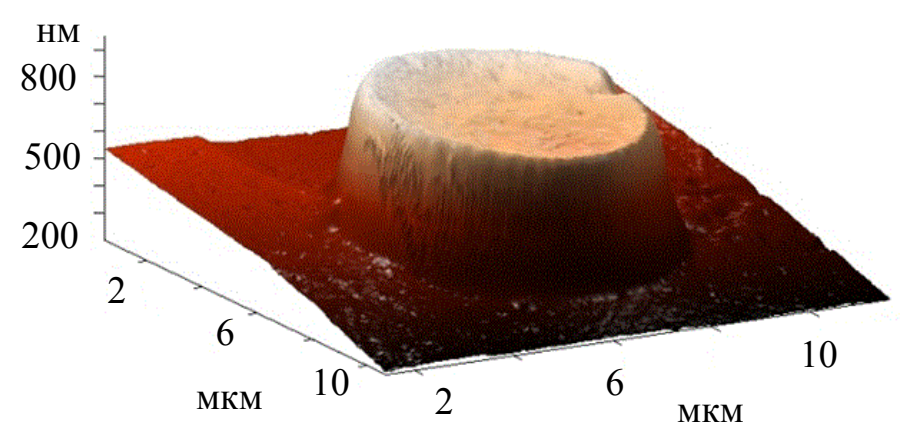

$a$

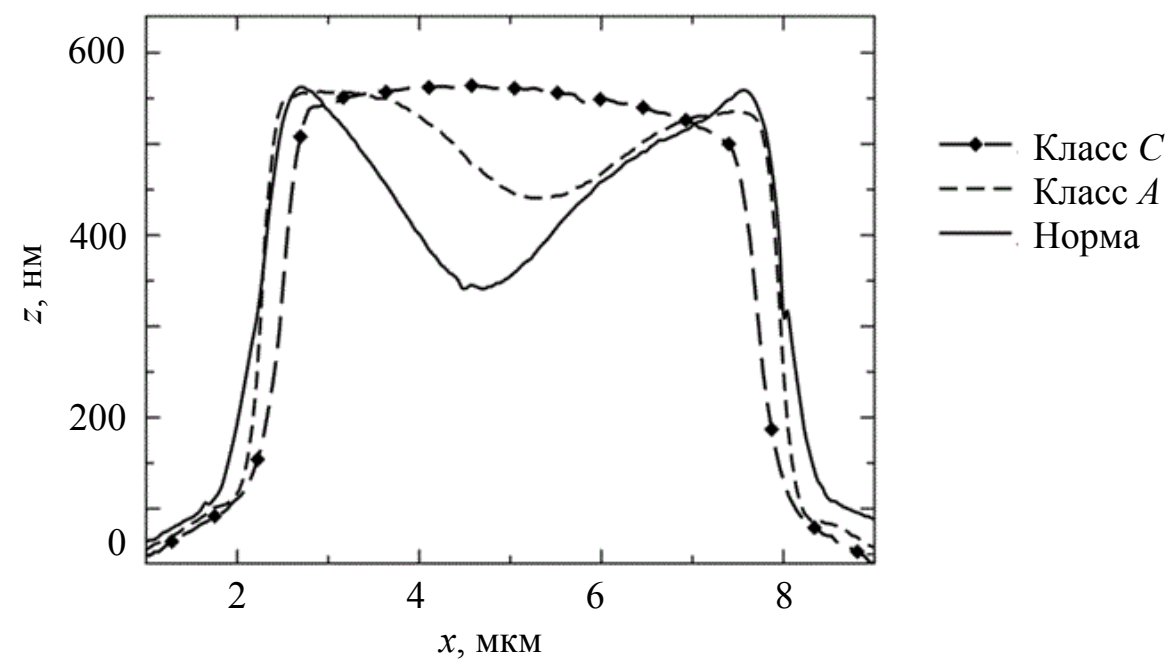

$\sigma$

Рис. 2. Морфология эритроцита, полученная при помощи атомносиловой микроскопии: $a$ - трехмерное изображение эритроцита; $\sigma$ - поперечный срез трехмерного изображения для эритроцитов при разной степени механической желтухи и в норме

Размеры эритроцита при разной степени механической желтухи и результаты оценки отношения внутриклеточного давления к показателю в норме

\begin{tabular}{|c|c|c|c|}
\hline $\begin{array}{c}\text { Степень } \\
\text { механической } \\
\text { желтухи }\end{array}$ & $\begin{array}{c}\text { Объем } \\
\text { эритроцитов, } \\
\text { мкм }\end{array}$ & $\begin{array}{c}\text { Отношение } \\
\text { объема к объему } \\
\text { в норме, \% }\end{array}$ & $\begin{array}{c}\text { Внутриклеточное } \\
\text { давление, кПа }\end{array}$ \\
\hline Норма & $7,5 \pm 2,0$ & $100,0 \pm 26,7$ & 0 \\
\hline Класс $A$ & $8,8 \pm 1,3$ & $117,3 \pm 17,4$ & 1,6 \\
\hline Класс $B$ & $10,2 \pm 1,9$ & $136,0 \pm 25,2$ & 3,4 \\
\hline Класс $C$ & $12,3 \pm 2,2$ & $164,0 \pm 29,3$ & 6,3 \\
\hline
\end{tabular}




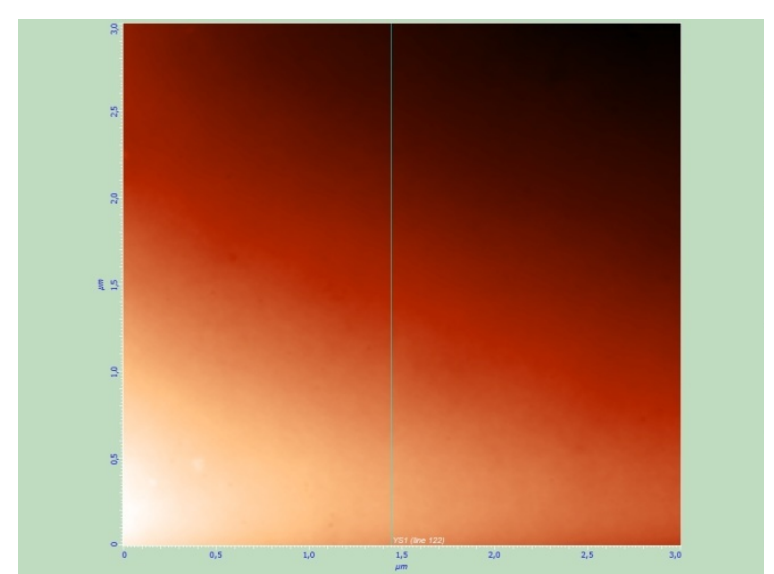

Норма

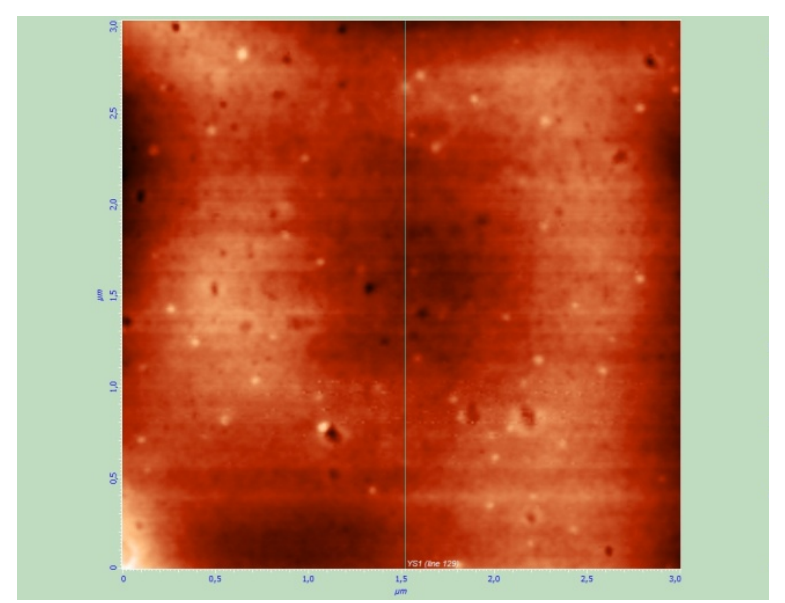

Класс $B$

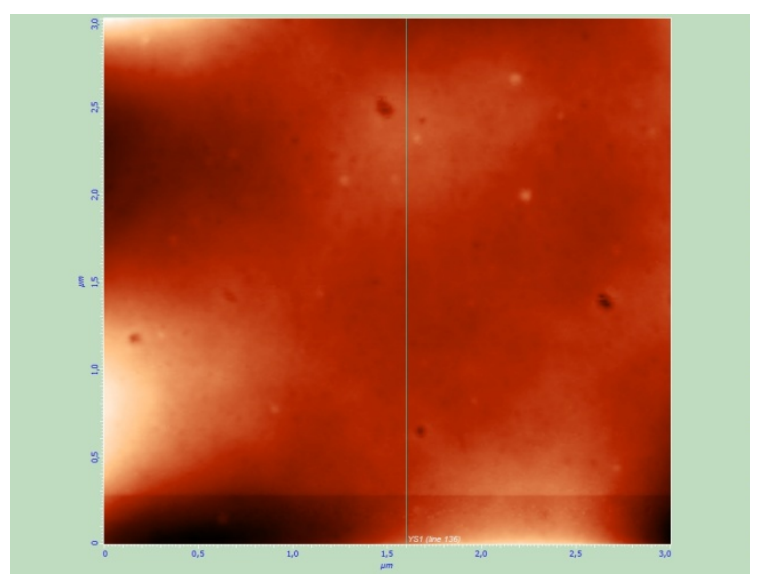

Класс $A$

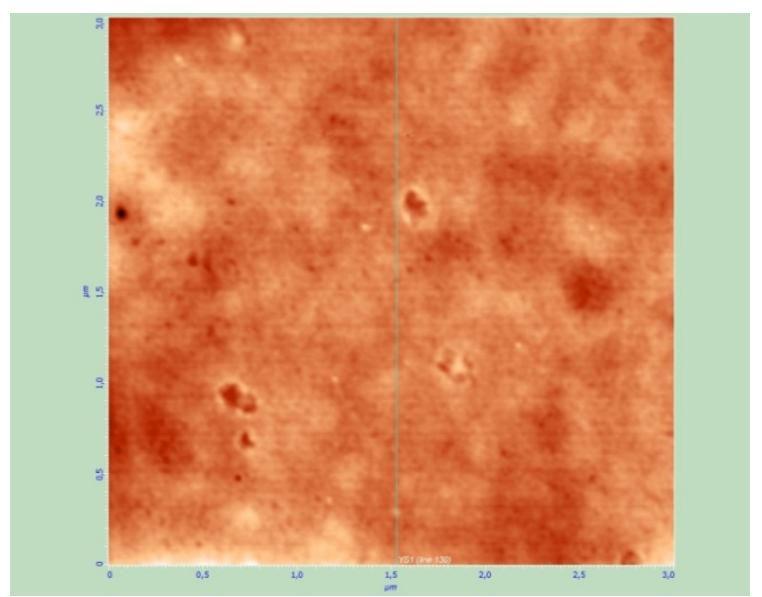

Класс $C$

Рис. 3. Сканы поверхности мембраны эритроцита, полученные при помощи атомно-силовой микроскопии с размером изображения $3 \times 3$ мкм, для эритроцитов с различным уровнем механической желтухи и в норме

\section{ЗАКЛЮЧЕНИЕ}

Таким образом, в работе предложен способ оценки внутриклеточного давления эритроцитов на основе численного моделирования морфологии эритроцита и данных атомно-силовой микроскопии. Проведен расчет внутриклеточного давления эритроцитов для экспериментальных животных при механической желтухе разной степени. Показано, что с ростом концентрации билирубина в крови происходит нарушение мембраны эритроцитов, в среднем увеличение их объема и существенное изменение внутриклеточного давления. Величина внутриклеточного давления в перспективе может быть использована для диагностики состояния мембраны эритроцитов.

\section{БЛАГОДАРНОСТИ}

Работа выполнена при поддержке Федеральной целевой программы «Исследования и разработки по приоритетным направлениям развития научнотехнологического комплекса России на 2014-2020 годы» (соглашение № 14.574.21.0025, уникальный идентификатор соглашения - RFMEFI57414X0025). 


\section{СПИСОК ЛИТЕРАТУРЫ}

1. Атауллаханов Ф.И., Корунова Н.О., Спиридонов И.С. Как регулируется объем эритроцита, или что могут или не могут математические модели в биологии // Биологические мембраны. - 2009. T. 26, № 3. - C. 163-179.

2. Винник Ю.С., Пахомова Р.А., Серова Е.В., Лейман А.В., Андреев Р.И. Хирургическая коррекция синдрома механической желтухи // Сибирский медицинский журнал. - 2012. - Т. 27, № 3. С. $116-119$.

3. Галимзянов Т.Р., Молотковский Р.Ю., Хейфец Б.Б., Акимов С.А. Энергия взаимодействия мембранных липидных доменов, вычисленная с учетом деформации поперечного изгиба и наклона // Письма в ЖЭТФ. - 2012. - Т. 96, № 10. - С. 756-761.

4. Гущина Ю.Ю., Плескова С.Н., Звонкова М.Б. Исследование различий морфологических параметров клеток крови человека методом сканирующей зондовой микроскопии // Поверхность. Рентгеновские, синхротронные и нейтронные исследования. - 2005. - № 1. - С. 48-53.

5. Дрозд Е.С., Чижик С.А., Константинова Е.Э. Атомно-силовая микроскопия структурномеханических свойств мембран эритроцитов // Российский журнал биомеханики. - 2009. - Т. 13, № 4. - С. 22-30.

6. Ивенс И., Скейлак Р. Механика и термодинамика биологических мембран: пер. с англ. - М.: Мир, 1982. - 352 c.

7. Калягина Н.В., Мартынов М.В., Атауллаханов Ф.И. Математический анализ регуляции объема эритроцита человека с учетом упругого воздействия оболочки эритроцита на обменные процессы // Биологические мембраны. - 2013. - Т. 30, № 2. - С. 115-127.

8. Нагорнов Ю.С. Моделирование морфологии и жесткости мембраны эритроцитов после фемтосекундного лазерного облучения // Российский журнал биомеханики. - 2013. - Т. 17, № 3 (61). C. $112-121$.

9. Нагорнов Ю.С., Жиляев И.В. Оптимизация формы эритроцита в соответствии с данными атомносиловой микроскопии // Математическая морфология. Электронный математический и биомедицинский журнал. - 2013. - Т. 12, № 1.

10. Asghari-Khiavi M., Wood B.R., Mechler A., Bambery K., Buckingham D.W., Cooke B.M., McNaughton D. Correlation of atomic force microscopy and Raman micro-spectroscopy to study the effects of ex vivo treatment procedures on human red blood cells // Analyst. - 2010. - Vol. 135. - P. 525-530.

11. Dulinska I., Targosz M., Strojny W., Lekka M., Czuba P., Balwierz W., Szymonski M. Stiffness of normal and pathological erythrocytes studied by means of atomic force microscopy // J. Biochem. Biophys. Methods. - 2006. - Vol. 66. - P. 1-11.

12. Evans E.A., Hochmuth R.M. Membrane viscoelasticity // Biophys. J. - 1976. - Vol. 16. - P. 1-11.

13. Hiroyoshi N., Masahiro O., Ou-Yang Z.C. Polygonal shape transformation of a circular biconcave vesicle induced by osmotic pressure // Phys. Rev. E. - 1996. - Vol. 54, № 3. - P. 2816-2826.

14. Lew V.L., Bookchin R.M. Volume $\mathrm{pH}$ and ion content regulation in human red cells: analysis of transient behaviour using an integrated mathematical model // Journal of Membrane Biology. - 1986. - Vol. 92. P. 57-74.

15. Martinov M.V., Vitvitsky V.M., Ataullakhanov F.I. Volume stabilization in human erythrocytes: combined effects of $\mathrm{Ca}_{2}+$-dependent potassium channels and adenylate metabolism // Biophys. Chem. - 1999. Vol. 80, № 3. - P. 199-215.

16. Nagornov Yu.S. Simulation of AFM data for erythrocytes membrane under femtosecond laser irradiation // Applied Cell Biology. - 2014. - Vol. 3, № 1. - P. 1-8.

17. Nowakowski R., Luckham P. Imaging the surface details of red blood cells with atomic force microscopy // Surface and Interface Analysis. - 2002. - Vol. 33, № 2. - P. 118-121.

18. O'Reilly M., McDonnell L., O'Mullane J. Quantification of red blood cells using atomic force microscopy // Ultramicroscopy. - 2001. - Vol. 86 (1-2). - P. 107-112.

19. Ou-Yang Z.C., Wolfgang H. Bending energy of vesicle membranes: General expressions for the first, second, and third variation of the shape energy and applications to spheres and cylinders // Physical Review A. - 1989. - Vol. 39, № 10. - P. 5280-5288.

20. Tu Z.C., Ou-Yang Z.C. Elastic theory of low-dimensional continua and its applications in bio- and nanostructures // J. Comput. Theor. Nanosci. - 2008. - Vol. 5. - P. 422-448. 


\title{
MODELLING OF ERYTHROCYTE MORPHOLOGY AND CALCULATION OF INTRACELLULAR PRESSURE ACCORDING TO ATOMIC FORCE MICROSCOPY DATA
}

\author{
Yu.S. Nagornov (Togliatti, Russia), R.A. Pahomova (Krasnoyarsk, Russia), \\ I.V. Zhilyaev (Rostov-on-Don, Russia), E.A. Voronova (Krasnoyarsk, Russia)
}

The present work is devoted to the analysis of three-dimensional data of atomic force microscopy for research of the morphology of red blood cells. Atomic force microscopy allows us to analyze the biomechanical properties of the membrane - elasticity, mobility of the surface layers, adhesion, molecular binding and electrostatics. In this paper, we built a biomechanical model of the erythrocyte, which allowed us to calculate the intracellular pressure of erythrocyte based on data of atomic force microscopy. In the model, the elastic properties are determined by the rigidity of the erythrocyte membrane and its interaction with the hemoglobin, wherein the internal contents of the erythrocyte were taken as a homogeneous body. The calculation was performed in two stages - first for the movable contents of the erythrocyte using Navier-Stokes equation, where the contents of the erythrocyte were imagined as a liquid, with the parameterization of the initial pressure and the formation of the geometry under the influence of internal and external forces, and then the calculation was carried out again by finite element method, where the inner contents of the erythrocyte were supposed solid, which excluded movement within the erythrocyte, but allowed us to determine the internal pressure, which was set in balance. As a result, we obtained the dependence of intracellular pressure on the morphology of red blood cell. We have proposed a method of estimating of intracellular pressure of erythrocytes based on numerical modelling and data of atomic force microscopy of erythrocytes scan, which involves a comparison of the experimental data with the results of numerical calculation. The method was applied to the data of atomic force microscopy of erythrocytes of experimental animals - dwarf domestic pigs with different degrees of obstructive jaundice and normal. It was shown that with increasing severity of the disease and the concentration of bilirubin in the blood there was an infringement of erythrocyte membranes, an average increasing their volume and a significant change of intracellular pressure compared with the normal.

Key words: erythrocyte, membrane biomechanics, intracellular pressure, atomic force microscopy, obstructive jaundice.

Получено 16 сентября 2015 